\title{
Selective Oxidation of Benzylic and Allylic Alcohols Using Strontium Manganate in the Presence of Lewis Acids in Solution and under Solvent-Free Conditions
}

\author{
M. Gholizadeh, ${ }^{\dot{*}, "}$ I. Mohammadpoor-Baltork, ${ }^{*}$ and B. Kharamesh \\ Department of Chemistry. Isfahan lniversity, Isfahan 81746-73441, Iran \\ ${ }^{\dagger}$ Department of Chemistry, Sabzevar Teacher Training liniversity, Sabzevar, Iran \\ Recened October 27, 2003
}

Key Words : Oxidation. Alcohols, Strontium manganate, Lewis acids

The oxidation of alcohols to their corresponding carbonyl compounds is an important reaction in synthetic organic chemistry. ${ }^{1}$ Among oxides and oxoanions of manganese, only manganese dioxide ${ }^{2}$ and potassium permanganate have been extensively studied in the oxidation of organic compounds. Several permanganate based oxidants such as potassium permanganate/dicyclohexyl-18-crown-6. ${ }^{+}$benzyltriethylammonium permanganate, ${ }^{5}$ tetrabutylammonium permanganate, ${ }^{6}$ bis(pyridine)silver permanganate, ${ }^{7}$ zinc permanganate supported on silica gel, ${ }^{8}$ barium permanganate," $\mathrm{KMnO}_{4} / \mathrm{CuSO}_{4} \cdot 5 \mathrm{H}_{2} \mathrm{O},{ }^{10} \mathrm{KMnO}_{4} / 7 \mathrm{rOCl}_{2} \cdot 8 \mathrm{H}_{2} \mathrm{O}^{\prime \prime}$ and potassium permanganate/montmorillonite $\mathrm{K}-10^{12}$ have been used for the oxidation of organic compounds. Unfortunately, some of these reagents suffer at least from one of the following disadvantages; cost of preparation, instability, long reaction time, powerful oxidant without selectivity, and dangerous procedures for their preparation. On the other hand, little attention has been paid to the oxidation properties of manganates and only a few reports are available in the literature..$^{1-15}$ Therefore, introduction of a new manganate oxidant for oxidation reactions is still in demand.

In this paper we wish to report oxidation of alcohols to their corresponding carbonyl compounds using strontium manganate in the presence of I.ewis acids in solution and under solvent-free conditions. Strontium manganate was prepared by the addition of strontium hydroxide to an aqueous solution of potassium manganate. The crystals of strontium manganate were collected and dried in vacuo. The experimental and calculated strontiun contents of the reagent are in very good agreement.

At first, the oxidation of 4-chlorobenzyl alcohol was investigated with this reagent in refluxing acetonitrile in the absence of Lewis acids. Only $40 \%$ conversion to 4-chlorobenzaldehyde was observed after $3 \mathrm{~h}$. In recent years, the effect of Lewis acids as promoter or catalysts for the oxidation of organic substrates has been reported. ${ }^{16}$. Therefore, the effect of Lewis acids upon the reactivity of $\mathrm{SrMnO}_{4}$ for the oxidation of 4-chlorobenzyl alcohol in refluxing acetonitrile was studied. The experimental results show that $\mathrm{AlCl}_{3}, \mathrm{FeCl} l_{3}, \mathrm{BiCl}_{3}$, and $\mathrm{SnCl}_{2} \cdot 2 \mathrm{H}_{2} \mathrm{O}$ are effective catalysts.

"Co-Corresponding Authors. Fax: $.98-311-6689732$, e-mail: I. Mohammadpoor-Baltork (imbaltork@sci.ui.ac,ir), M. Gholizadeh (m_gholizadeh@stlu.ac.ir)

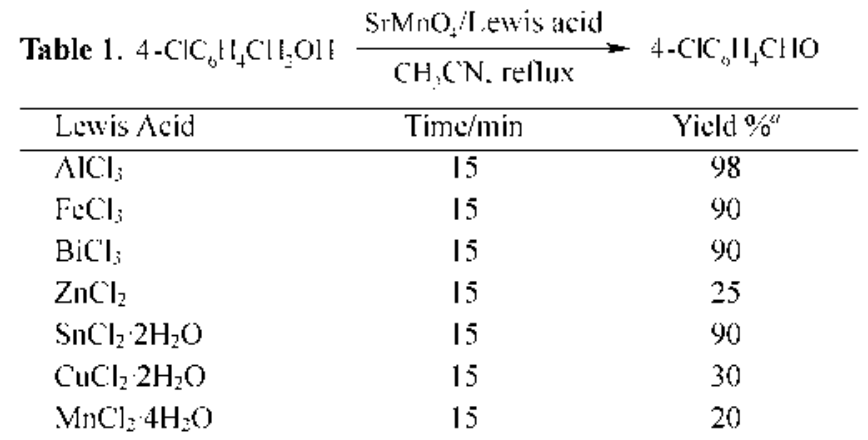

"Isolated yiclds.

Therefore, the more familiar and the most effective one, $\mathrm{AlCl}_{3}$, was chosen as catalyst through this investigation (Table 1). As we have mentioned in our previous publications, ${ }^{16 \text { bil.d.c }}$ some of the reagents under our investigations are effective under nonaqueous conditions when catalyzed with $\mathrm{AlCl}_{\text {s. }}$. This trend has been also observed for the oxidation of alcohols with strontium manganate. Unfortunately the mechanism of the reaction is not clear to us.

The effects of solvents upon the oxidation ability of $\mathrm{SrMnO}_{4}$ in the presence of $\mathrm{AlCl}_{3}$ for the oxidation of 4chlorobenzyl alcohol was also investigated; the best result was achieved using acetonitrile (Table 2).

Primary and secondary benzylic alcohols are oxidized cleanly and easily to their corresponding aldehydes and ketones in excellent yields (lable 3, entries 1-18). It is important to note that further oxidation of aldehydes to their carboxylic acids was not observed. Under the same reaction conditions, allylic alcohols are selectively oxidized to their $\alpha, \beta$-unsaturated carbonyl compounds without the cleavage of carbon-carbon double bonds (entries 19 and 20). In contrast, manganese dioxide, which has been widely used for the oxidation of allylic alcohols, requires a large excess

Table 2. 4- $-\mathrm{CK}_{6} \mathrm{H}_{4} \mathrm{CH}_{2} \mathrm{OH} \frac{\mathrm{SrMnO}_{4} \mathrm{AlCl}_{4}}{\text { Solvent. reflux }} 4 \cdot \mathrm{ClC}_{4} \mathrm{H}_{2} \mathrm{CHO}$

\begin{tabular}{lcccc}
\hline Solvent & $\mathrm{CH}_{3} \mathrm{CN}$ & THF & $\mathrm{CH}_{2} \mathrm{Cl}_{2}$ & ${ }_{n \text {-Hexanc }}$ \\
\hline Time $\min$ & 15 & 60 & 60 & 60 \\
Yield $\% \%^{\prime \prime}$ & 98 & 75 & 15 & 40
\end{tabular}

"Isolated yields. 
Table 3. Oxidation of alcohols to carbonyl compounds with $\left.\mathrm{SrMnO}_{4} / \mathrm{A} \mid \mathrm{C}\right]_{3}$

\begin{tabular}{|c|c|c|c|c|}
\hline \multirow{2}{*}{ Fintry } & \multirow{2}{*}{ Sulsstrale } & \multirow{2}{*}{ Product" } & \multicolumn{2}{|c|}{ Yicld \% (Timeimin) } \\
\hline & & & Solution & Solvent-free \\
\hline 1 & $\mathrm{C}_{0} \mathrm{H}_{5} \mathrm{Cll}_{2} \mathrm{O} \mathrm{Ol}$ & $\mathrm{C}_{0} \mathrm{H}_{5} \mathrm{Cll} O \mathrm{O}$ & $96(15)$ & $95(90)$ \\
\hline 2 & $2-\mathrm{ClC}_{6} \mathrm{II}_{4} \mathrm{Cl}_{2} \mathrm{OH}$ & $2-\mathrm{ClC}_{6} \mathrm{I}_{+} \mathrm{CHO}$ & $96(20)$ & $95(120)$ \\
\hline 3 & $4-\mathrm{ClC}_{6} \mathrm{Il}_{4} \mathrm{Cl}_{2} \mathrm{OH}$ & $4-\mathrm{ClC}_{6} \mathrm{I}_{+} \mathrm{ClO} O \mathrm{O}$ & $98(15)$ & $98(120)$ \\
\hline 4 & $2,4-\mathrm{Cl}_{2} \mathrm{C}_{3} \mathrm{I}_{3} \mathrm{CH}_{2} \mathrm{OII}$ & $2.4-\mathrm{Cl}_{2} \mathrm{C}_{6} \mathrm{I}_{3} \mathrm{CIIO}$ & $99(15)$ & $98(120)$ \\
\hline 5 & $2-\mathrm{H}_{3} \mathrm{C}_{6} \mathrm{II}_{4} \mathrm{Cl}_{2} \mathrm{OH}$ & $2-\mathrm{HrCu}_{4} \mathrm{I}_{+} \mathrm{CllO}$ & $97(10)$ & $97(120)$ \\
\hline 6 & $4-\mathrm{H}_{3} \mathrm{Cll}_{4} \mathrm{Cl}_{2} \mathrm{OHI}$ & $4-\mathrm{BrC}_{6} \mathrm{II}_{+} \mathrm{CllO}$ & $99(10)$ & $98(120)$ \\
\hline 7 & $3-\mathrm{MeOC}_{3} \mathrm{I}_{4} \mathrm{ClI}_{2} \mathrm{OHI}$ & $3-\mathrm{MeOC}_{6} \mathrm{Il}_{4} \mathrm{CIIO}$ & $97(10)$ & $97(90)$ \\
\hline 8 & 4-MeOCol $\mathrm{H}_{4} \mathrm{ClI}_{2} \mathrm{OlI}$ & $4-\mathrm{MeOC}_{6} \mathrm{Il}_{4} \mathrm{CHIO}$ & $98(10)$ & $98(60)$ \\
\hline 9 & $4-(\mathrm{Me})_{2} \mathrm{CHCC}{ }_{6} \mathrm{Il}_{+} \mathrm{Cl}_{2} \mathrm{OlI}$ & $4-(\mathrm{Me})_{2} \mathrm{CHC} \mathrm{Cl}_{4} \mathrm{Cl} \mathrm{OO}$ & $97(15)$ & $98(60)$ \\
\hline 10 & $4-(\mathrm{Me})_{3} \mathrm{CC}_{3} \mathrm{ll}_{4} \mathrm{CH}_{2} \mathrm{OHI}$ & $4-(\mathrm{Me})_{3} \mathrm{CC}_{6} \mathrm{I}_{4} \mathrm{CH} \mathrm{O}$ & $98(15)$ & $96(60)$ \\
\hline 11 & $4-\mathrm{PhCl}_{2} \mathrm{OC}_{6} \mathrm{Ll}_{4} \mathrm{Cl}_{2} \mathrm{OH}$ & $4-\mathrm{PhCl}_{2} \mathrm{OC}_{6} \mathrm{II}_{4} \mathrm{CllO}$ & $99(10)$ & $99(60)$ \\
\hline 12 & $\left(\mathrm{C}_{3} \mathrm{I}_{5}\right)_{2} \mathrm{ClOH}$ & $\left(\mathrm{C}_{6} \mathrm{H}_{3}\right)_{2} \mathrm{CO}$ & $99(20)$ & $97(120)$ \\
\hline 13 & $\mathrm{C}_{6} \mathrm{H}_{5} \mathrm{Cl}(\mathrm{OII}) \mathrm{Me}$ & $\mathrm{C}_{0} \mathrm{H}_{5} \mathrm{COMe}$ & $97(20)$ & $95(120)$ \\
\hline 14 & $4-\mathrm{ClC}_{6} \mathrm{IL}_{+} \mathrm{Cl}(\mathrm{OH}) \mathrm{Me}$ & 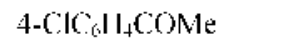 & $98(20)$ & $96(120)$ \\
\hline 15 & $4-\mathrm{MeC}_{6} \mathrm{H}_{4} \mathrm{Cl}(\mathrm{OJ}) \mathrm{Me}$ & 4-MeCol $\mathrm{MCOMe}_{4}$ & $97(20)$ & $98(120)$ \\
\hline 16 & & & $97(15)$ & $96(90)$ \\
\hline 17 & & & $98(10)$ & $97(60)$ \\
\hline 18 & & & $88(60)$ & $90(120)$ \\
\hline 19 & $\mathrm{C}_{6} \mathrm{H}_{5} \mathrm{C} \mathrm{Cl}=\mathrm{CIICl}_{2} \mathrm{OHI}$ & $\left(\mathrm{C}_{6} \mathrm{H}_{5} \mathrm{COI}=\mathrm{CIICl}\right)$ & $95(15)$ & $94(120)$ \\
\hline 20 & $\mathrm{C}_{6} \mathrm{H}_{5} \mathrm{C} \cdot \mathrm{H}=\mathrm{C} \cdot \mathrm{HCH}(\mathrm{OH}) \mathrm{Pl}$ & $\mathrm{C}_{6} \mathrm{H}_{s} \mathrm{CH}=\mathrm{CHCOPh}$ & $96(15)$ & $93(120)$ \\
\hline 21 & $2-\mathrm{NO}_{2} \mathrm{C}_{6} \mathrm{H}_{6} \mathrm{CH}_{2} \mathrm{OH}$ & $2-\mathrm{NO}_{2} \mathrm{C}_{6} \mathrm{H}_{4} \mathrm{CHO}$ & $42(90)$ & $40(120)$ \\
\hline 22 & $3-\mathrm{NO}_{2} \mathrm{C}_{6} \mathrm{H}_{6} \mathrm{CH}_{2} \mathrm{OH}$ & $3-\mathrm{NO}_{2} \mathrm{C}_{3} \mathrm{H}_{1} \mathrm{CHO}$ & $46(90)$ & $41(120)$ \\
\hline 23 & $4-\mathrm{NO}_{2} \mathrm{C}_{6} \mathrm{H}_{6} \mathrm{CH}_{2} \mathrm{OH}$ & $4-\mathrm{NO}_{2} \mathrm{C}_{3} \mathrm{H}_{4} \mathrm{CHO}$ & $47(90)$ & $44(120)$ \\
\hline 24 & $\mathrm{C}_{6} \mathrm{H}_{5} \mathrm{C} \cdot \mathrm{H}(\mathrm{Me}) \mathrm{CH}_{2} \mathrm{OH}$ & $\mathrm{C}_{6} \mathrm{H}_{s} \mathrm{CH}\left(\mathrm{ML}_{2}\right) \mathrm{CHO}$ & $54(60)$ & $50(120)$ \\
\hline 25 & $\mathrm{CH} ;\left(\mathrm{CH}_{2}\right) \times \mathrm{CH}_{2} \mathrm{OH}$ & $\mathrm{CH}_{3}\left(\mathrm{CH}_{2}\right)_{4} \mathrm{CHO}$ & $30(90)$ & $34(120)$ \\
\hline 26 & $\mathrm{CH}_{3}\left(\mathrm{CH}_{2}\right)_{6} \mathrm{CH}_{2} \mathrm{OH}$ & $\mathrm{CH}_{3}\left(\mathrm{CH}_{2}\right)_{6} \mathrm{CHO}$ & $33(90)$ & $30(120)$ \\
\hline 27 & Cyclohexanol & Cyclohexanone & $37(90)$ & $35(120)$ \\
\hline 28 & Cycloheptanol & Cycloheptanone & $38(90)$ & $37(120)$ \\
\hline
\end{tabular}

"Al] products were identilied by comparison of their physical and spectral dala with those of authentic samples. "Isolated yields.

of the reagent and long reaction times for successful oxidations. ${ }^{17}$ Benzylic alcohols with nitro-substituent and also saturated alcohols are more resistant towards oxidation with $\mathrm{SrMnO}_{1} / \mathrm{AlCl}_{3}$ and their corresponding carbonyl compounds were obtained in relatively low yields (entries 2]-28).

The oxidation of alcohols with this reagent system was also investigated under solvent-free conditions. As shown in Table 3 , under these conditions, the yields of the products are comparable with the solution reactions, but the reaction times are longer:

In order to show the advantage of strontium manganate over potassium manganate in oxidation of allylic alcohols, the oxidation of cinnainyl alcohol (Table 3 , entry 19) to cinnamaldehyde with potassium manganate was investigated in both solution and under solvent-free conditions. The experimental results show that in comparison with strontium manganate, the yields of the reactions are considerably lower with potassium manganate $(55 \%$ in solution and $52 \%$ under solvent-free conditions).

In order to further extend the scope of this method, we have also studied the competitive oxidation of alcohols with this reagent in both solution and under solvent-free conditions. The experimental results show that benzylic and allylic alcohols are oxidized in the presence of saturated alcohols with excellent selectivity (Table 4). This may be considered as a useful practical achievement in oxidation reactions.

In conclusion, we have developed a comvenient method for the oxidation of alcohols. In addition, high chemoselectivity, high yields, short reaction times, and easy workup are noteworthy advantages of this method. 
Table 4. Competitive oxidation of alcohols with $\mathrm{SrMnO}_{4} / \mathrm{AlCl}_{3}$

\begin{tabular}{|c|c|c|c|c|}
\hline \multirow{2}{*}{ Entry } & \multirow{2}{*}{ Substrate } & \multirow{2}{*}{ Product } & \multicolumn{2}{|c|}{ Yield $\%{ }^{a}($ Time $/ \mathrm{min})$} \\
\hline & & & Solution & Solvent-free \\
\hline \multirow[t]{2}{*}{1} & $2-\mathrm{ClC}_{5} \mathrm{H}_{4} \mathrm{CH}_{2} \mathrm{OH}$ & $2-\mathrm{ClC}_{6} \mathrm{H}_{4} \mathrm{CHO}$ & $98(20)$ & $98(120)$ \\
\hline & Cyclohexanol & Cyclohexanone & 0 & 0 \\
\hline \multirow[t]{2}{*}{2} & $4-\mathrm{MeOC}_{6} \mathrm{H}_{4} \mathrm{CH}_{2} \mathrm{OH}$ & $4-\mathrm{MeOC}_{6} \mathrm{H}_{4} \mathrm{CHO}$ & $100(10)$ & $100(60)$ \\
\hline & $\mathrm{CH}_{3}\left(\mathrm{CH}_{2}\right)_{6} \mathrm{CH}_{2} \mathrm{OH}$ & $\mathrm{CH}_{3}\left(\mathrm{CH}_{2}\right)_{6} \mathrm{CHO}$ & 0 & 0 \\
\hline \multirow[t]{2}{*}{3} & $4-\mathrm{BrC}_{6} \mathrm{H}_{4} \mathrm{CH}_{2} \mathrm{OH}$ & $4-\mathrm{BrC}_{6} \mathrm{H}_{4} \mathrm{CHO}$ & $100(10)$ & $100(120)$ \\
\hline & $\mathrm{CH}_{3}\left(\mathrm{CH}_{2}\right) \times \mathrm{CH}_{2} \mathrm{OH}$ & $\mathrm{CH}_{3}\left(\mathrm{CH}_{2}\right)_{3} \mathrm{CHO}$ & 0 & 0 \\
\hline \multirow[t]{2}{*}{4} & $\mathrm{C}_{n} \mathrm{H}_{3} \mathrm{CH}=\mathrm{CHCH}_{2} \mathrm{OH}$ & $\mathrm{C}_{6} \mathrm{H}_{3} \mathrm{CH}=\mathrm{CHCHO}$ & $97(15)$ & $96(120)$ \\
\hline & Cycloheptanol & Cycloheptanone & 0 & 0 \\
\hline
\end{tabular}

"GLC vields.

\section{Experimental Section}

Preparation of strontium manganate $\left(\mathrm{SrMnO}_{4}\right)$. In a round-bottomed flask ( $250 \mathrm{~mL}$ ) equipped with a magnetic stirrer and a condenser, a warm solution of potassium manganate $(0.05 \mathrm{~mol})$ in distilled water $(60 \mathrm{~mL})$ was prepared. To this solution, strontium hydroxide $(0.05 \mathrm{~mol})$ was added and the nixture was stirted for $0.5 \mathrm{~h}$. The reaction mixture was filtered and the solid material was washed with distilled water. The resulting crystals were dried in a desiccator under vacuo to afford strontium manganate in $87 \%$ yield. Found: $\mathrm{Sr}, 41.96 \%$. Calcd for $\mathrm{SrMnO}_{4}$ : $\mathrm{Sr} .42 .42 \%$.

General procedure for oxidation of alcohols in solution. In a round-bottoned flask $(50 \mathrm{~mL})$ equipped with a magnetic stirrer and a condenser, a solution of alcohol (I mmol) in $\mathrm{CH}_{3} \mathrm{CN}(10 \mathrm{~mL})$ was prepared. $\mathrm{SrMnO}_{4}$ ( $\mathrm{l}$ mumol) and $\mathrm{AlCl}_{\hat{3}}(0.75 \mathrm{mumol})$ was added to the solution and the mixture was refluxed for $10-90 \mathrm{~min}$. The progress of the reaction was followed by TLC (eluent: $\mathrm{CCl}_{4} / \mathrm{EtOAC}^{4} 4 / 1$ ). The reaction mixture was filtered and the solid material was washed with $\mathrm{CH}_{3} \mathrm{CN}$ ( $15 \mathrm{~mL}$ ). The filtrate was exaporated and the resulting crude material was purified by column chromatography on silica gel to afford the pure product (Table 3).

General procedure for oxidation of alcohols under solvent-free conditions. A mixture of alcohol ( $1 \mathrm{mmol})$. $\mathrm{SrMnO}_{4}(1 \mathrm{mmol})$ and $\mathrm{AlCl}_{3}(0.75 \mathrm{mmol})$ were heated on an oil bath $\left(70^{\circ} \mathrm{C}\right)$ for $60-120 \mathrm{~min}$. The progress of the reaction was followed by TLC (eluent: $\mathrm{CCl}_{4} / \mathrm{EtOAc:} 4 / 1$ ). After completion of the reaction. the mixture was cooled to room temperature and extracted with $\mathrm{CH}_{2} \mathrm{Cl}_{3}$. The solvent was evaporated and the resulting crude material was purified by column chromatography on silica gel to afford the pure product (Table 3).

Acknowledgement. We are thankful to the Sabzevar
Teacher Training and Isfahan University Research Councils for the support of this work.

\section{References}

1. Hudlicky: M. Oxidations in Organic Chemistry, ACS Monograph 186. Washington1. 1999

2. Fatiadi. A. J. Symthesis 1976. 133.

3. Fieser. L. F.: Fieser. M. Reagent for Organic Snmesis: Wiley New York, 1967; Vol. 1

4. Sam. D. J.: Simmons, H. E. J. Am. Chem. Soc. 1972. 94. 4024.

5. Schmidt. H. J:- Schafer. H. J. Angew: Chem. Int. Ed. Engl. 1979. 18.68

6. (a) Sala. T.: Sargent. M. V. J. Chent. Sax. Chem. Commm. 1978. 253. (b) Herriott. A. W.: Picker. D. Tetwahedron Lett. 1974. 1511

7. Firouzabadi. H.; Vessal. B.: Naderi, M. Tetwahedron Lett. 1982. 23. 1847.

8. Wolfe, S.; Ingold, C. F. . . Am. Chem. Soc. 1983, 105, 7755.

9. Firouzabadi. H.: Seddighi. M.: Mottaghinejad. E.: Bolourchiant. M. Tetrahedhon 1990.46 .6869

10. (a) Noureldin. N. A.: Lee. D. G. J. Org Chem. 1982. 77.2790 (b) Shatani. A.: Lee. D. G. Tetrohedron Lett. 2001. 42,5833

11. Firouzabadi, H.; Fakoorpour, M.; Hazarkhani, H. Symh. Conmun. 2001. 31,3859

12. Mohammadpoor-Baltork. I.: Khodaei. M. M.: Hajipour. A. R. Aslani. E. Wonatsh. Chent 2003. 134.539.

13. (a) Stewart. R. J. Am. Chem. Soc. 1957. 79. 3057, (b) Rigby. W. J. Chent. Soc. 1956, 2452.

14. (a) Firouzabadi. H.; Ghaderi. E. Tetahedron Lett 1978, 839. (b) Firouzabadi, H; Mostafavipoor. Z. Bull. Chem. Soc. Jpn. 1983. 56.914

15. Schlesinger. H. I.: Mullinir. R. D.: Popotf. S. J. Ind. Eng. Chent. 1919. 11.317.

16. (a) Firouzabadi. H.: Mohammadpoor-Baltork, I. Sinh Conmum. 1994. 24, 1065. (b) Firouzabadi. H.; Mohammadpoor-Baltork. I. Bull. Chem. Soc. Jpn. 1995. 68. 2319. (c) Firouzabadi. H. Sardarian. A. R.: Badparqa. H. Bull. Chem. Soc. Jpn. 1996. 69. 685. (d) Mohammadpoor-Baltork. I.: Nourozi. A. R. Swhthesis 1999. 487. (e) Mohammadpoor-Baltork. I.: Sadeghi. M. M: Adibi. A.-H. Molecules 2001,900.

17. House. H. O. Hodem Synthetic Reactions: Benjamin, W. A.: New York. 1972, p 265. 